\title{
Septic Systems and Springs Water Quality: An Overview for Florida ${ }^{1}$
}

\author{
Mary Lusk, Andrea Albertin, Whitney Elmore, William Lester, and James Moll²
}

\section{Introduction and Purpose}

Approximately $30 \%$ of Florida's population relies on septic systems or on-site sewage treatment and disposal systems (OSTDS) to treat and dispose of household wastewater, which includes all water from bathrooms, kitchens, and laundry machines. This translates to about 2.6 million systems in operation in Florida, discharging about 426 million gallons of wastewater per day to underlying soil and groundwater (Figure 1) (Meeroff et al. 2008). Wastewater carries pathogens, nutrients (nitrogen and phosphorus), and trace organic chemicals that may be harmful to human health and ecosystem functioning (Lusk et al. 2017). Thus, proper treatment of wastewater is crucial. While septic systems can be one means of effective wastewater treatment, there are some special considerations for their use in Florida because of unique geography and sandy soils.

In Florida, much of the regulatory and political discussion around septic systems centers on the nitrogen $(\mathrm{N})$ that they may contribute to groundwater, springs, and coastal waters. This human-caused $\mathrm{N}$ loading is one source of $\mathrm{N}$ that can fuel excess algal growth in water bodies such as springs, which are fed directly by groundwater, or in coastal areas that often have older, densely spaced septic systems that may be no longer functioning properly. To address $\mathrm{N}$ loading from septic systems in Florida, legislation that became effective in 2017 requires many conventional septic systems to be replaced with alternative nitrogen-removing
OSTDS technology in many of the state's springsheds (the area of land that contributes groundwater flow to a spring), and several coastal communities have begun attempts to enact similar legislation or to remove all septic systems entirely. The purpose of this document is to explain the basics of how septic systems work and how they can affect springs water quality in Florida, with a special emphasis on potential $\mathrm{N}$ loading from septic systems. This document is intended for homeowners, the general public, and county, city, and other local personnel tasked with managing water quality in areas with septic systems.

\section{How do conventional septic systems work?}

A conventional septic system is made up of a septic tank (a watertight container buried in the ground) and a drainfield, or leach field. The septic tank allows for separation of solids (which settle on the bottom as sludge) from oils and grease (which float to the top and form a scum layer). The liquid wastewater, which is in the middle layer of the tank, flows out through pipes into the drainfield (Figure 2).

The drainfield is a series of trenches or a single bed with perforated pipes that allow treated effluent from the septic tank to infiltrate into the underlying soil, with the intent that wastewater contaminants will be removed by filtering and/or interaction with soil surfaces (Figure 3). Most

1. This document is SL476, one of a series of the Department of Soil and Water Sciences, UF/IFAS Extension. Original publication date October 2020. Visit the EDIS website at https://edis.ifas.ufl.edu for the currently supported version of this publication.

2. Mary Lusk, assistant professor, Department of Soil and Water Sciences, UF/IFAS Gulf Coast Research and Education Center; Andrea Albertin, regional specialized agent-northwest; Whitney Elmore, county Extension director and Extension agent III, UF/IFAS Extension Pasco County; Extension agent II, UF/IFAS Extension Hernando County; and James Moll, coordinator, education/training, UF/IFAS Extension Pasco County; UF/IFAS Extension, Gainesville, FL 32611.

The Institute of Food and Agricultural Sciences (IFAS) is an Equal Opportunity Institution authorized to provide research, educational information and other services

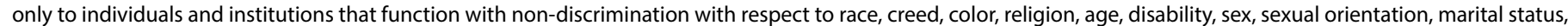

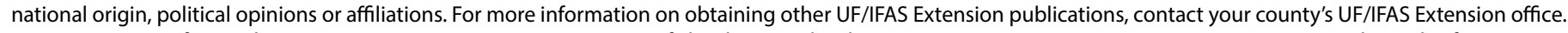
U.S. Department of Agriculture, UF/IFAS Extension Service, University of Florida, IFAS, Florida A \& M University Cooperative Extension Program, and Boards of County Commissioners Cooperating. Nick T. Place, dean for UF/IFAS Extension. 
contaminant treatment takes place in the drainfield soil; contaminants such as pathogens and nutrients are filtered, removed, and/or broken down into safer forms as the septic effluent moves through the soil. These processes are optimized in soil that is unsaturated, or not completely filled with water. Permitting regulations in Florida require that the bottom of the drainfield be at least 24 inches above the wet-season high water table to allow for filtration through unsaturated soils. For more information on how septic systems work, see EDIS publication SL347 (https://edis.ifas. ufl.edu/ss549).

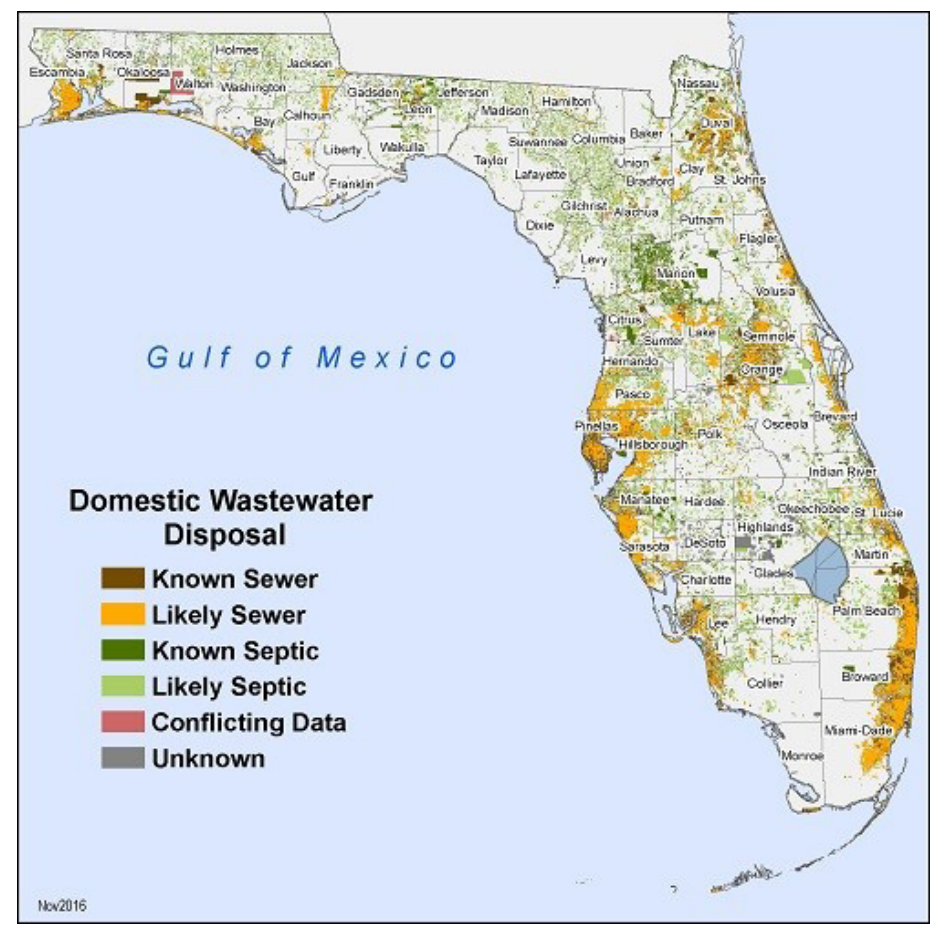

Figure 1. Florida map showing domestic wastewater disposal methods. Areas with septic systems are shown in green. Credits: Floridahealth.gov. http://www.floridahealth.gov/ environmental-health/onsite-sewage/research/flwmi/index.html

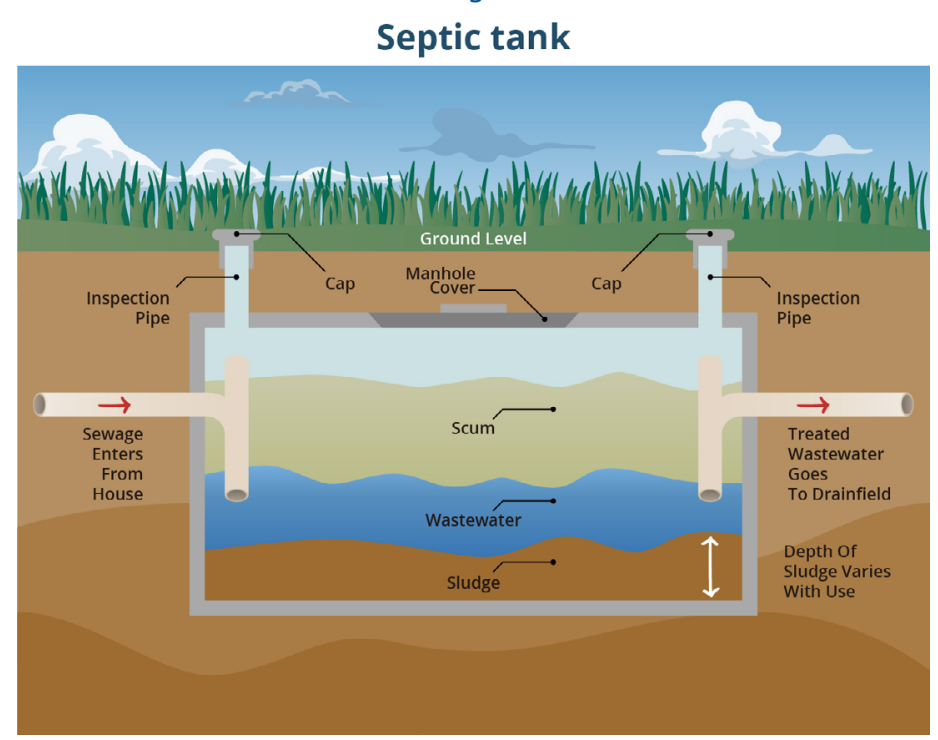

Figure 2. A conventional septic tank.

Credits: UF/IFAS GCREC Urban Soil and Water Quality Lab

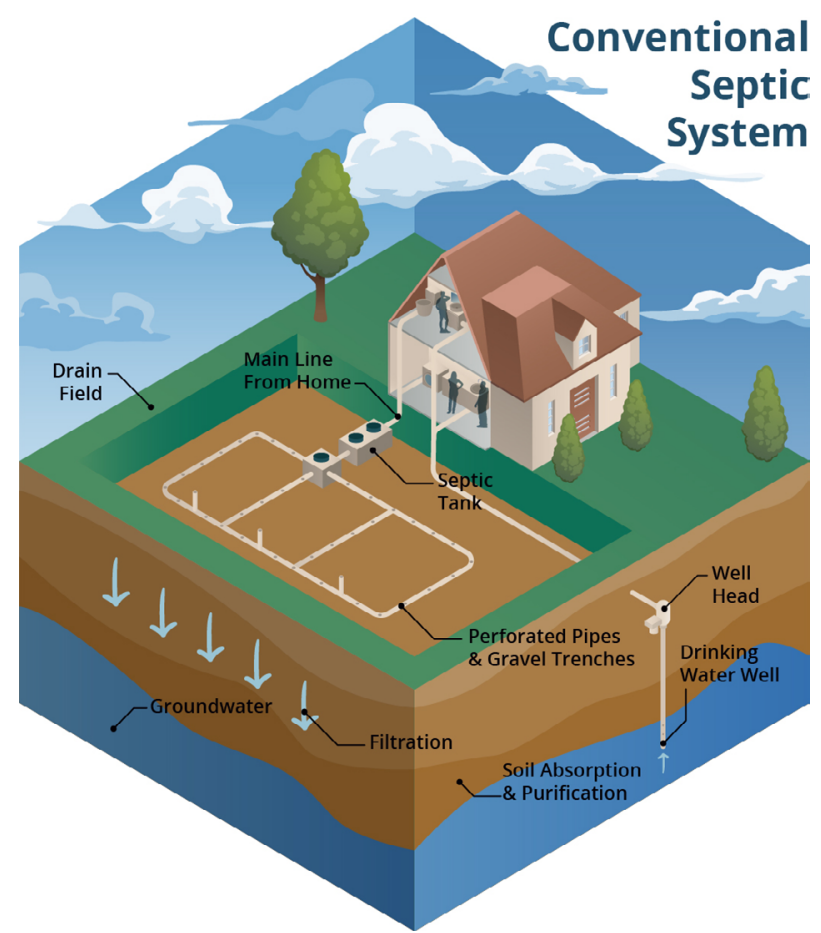

Figure 3. A conventional septic system, showing the septic tank and drainfield.

Credits: UF/IFAS GCREC Urban Soil and Water Quality Lab

The State of Florida has established guidelines for where and how septic systems can be sited or installed in Florida. These regulations account for factors such as the number of people in a home and the expected waste volume from the home, the local soil type and the ability of the soil to filter pollutants, depth to the water table, and distance to water resources such as a drinking-water well or wetland. See Table 1 for some standard "setbacks," or distances required in Florida between a septic system and various other landscape features.

\section{Contaminant Removal in Conventional Septic Systems}

Conventional septic systems are a technology that has been widely used in populated areas since the 1940s. They are designed from a public health perspective, and as long as they are properly sited and maintained (i.e., placed in adequate soils with proper setbacks from the water table and pumped every 2-3 years), they are usually successful in removing pathogens and protecting human health, which is their primary role. For more information about the fate of pathogens (including bacteria, viruses, and protozoans) in septic systems, see EDIS publications SL350 (https:// edis.ifas.ufl.edu/ss552) and SL351 (https://edis.ifas.ufl.edu/ ss553).

Conventional septic systems were not designed, however, to completely remove nutrients or the trace organic chemicals 
from pharmaceuticals and personal care products now ubiquitous in the modern waste stream. For example, a conventional septic tank removes only about $30 \%$ of the $\mathrm{N}$ and about $60 \%$ of the phosphorus (P) that come in (Lusk et al. 2017). Because $\mathrm{N}$ is the most common pollutant of concern related to septic systems in Florida, here is an illustrative example of how much $\mathrm{N}$ can be contributed to underlying groundwater from a conventional residential septic system: In a typical household, septic tanks receive about $9.1 \mathrm{lb} \mathrm{N} /$ person/year. Of that, approximately $6.4 \mathrm{lb} \mathrm{N} /$ person/year moves through the system, potentially making its way to groundwater, springs, or adjacent coastal waters (Toor, Lusk, and Obreza 2011). To see how this can add up, the Florida Department of Environmental Protection (FDEP) estimates that septic systems contribute more than 280,000 pounds of $\mathrm{N}$ to groundwater of the Weeki Wachee Spring each year (FDEP 2018). Contributions of septic systems to the $\mathrm{N}$ loadings of various other Florida springs have also been estimated (Table 2).

The reason for limited removal of $\mathrm{N}$ from conventional septic systems is that $\mathrm{N}$ in septic system effluent is mostly in the form of ammoniun $\left(\mathrm{NH}_{4}^{+}\right)$(Toor, Lusk, and Obreza 2011). This $\mathrm{NH}_{4}^{+}$is quickly converted to nitrate $\left(\mathrm{NO}_{3}^{-}\right)$in soils, especially in the well-drained sandy soils common in Florida. Nitrate is highly mobile in soils and can quickly leach to underlying groundwater. For more information about the fate of $\mathrm{N}$ and $\mathrm{P}$ from septic systems, see EDIS publications SL348 (https://edis.ifas.ufl.edu/ss550) and SL349 (https://edis.ifas.ufl.edu/ss551).

While research is still ongoing for trace organic chemicals in septic systems, Florida studies have detected various pharmaceuticals and household chemicals in septic system effluent (Yang et al. 2016). These chemicals are present in nanogram levels (very small concentrations) in septic system effluent, but they are known to have harmful effects on various aquatic organisms at even the nanogram level. For example, some fish species exposed to trace levels of wastewater-derived human hormones experience reproductive harm (Brian et al. 2007). For more information about the fate of trace organic chemicals in septic systems and their effects on the environment, see EDIS publication SL352 (https://edis.ifas.ufl.edu/ss553).

\section{The Florida Springs and Aquifer Protection Act and Septic System Regulations}

Florida has more first magnitude springs than any other state. First magnitude springs are those that discharge at least 64.6 million gallons of water per day or 100 cubic feet per second. All springs are fed by groundwater, and as such, water quality in a spring is tied to the water quality of the groundwater that flows into the spring. In recognition of the fact that water quality is diminished in many Florida springs, the 2016 Florida Water Bill created the Florida Springs and Aquifer Protection Act to protect and restore flows and water quality in the state's Outstanding Florida Springs (OFS), a new class of protected water bodies in the state including 24 first magnitude springs and 6 second magnitude springs (Figure 4). The Florida Department of Environmental Protection (FDEP) has established through its water-quality monitoring program that 24 of the 30 OFS are impaired by excess nitrate; therefore, efforts to restore water quality in the springs have centered largely on identifying and controlling $\mathrm{N}$ sources to groundwater. In doing this, FDEP used a computer model called the Nitrogen Source Inventory Loading Tool (NSILT). The NSILT model uses data on land use, population, geography, expected behaviors such as how much $\mathrm{N}$ humans add to the environment, and the best available scientific data on how $\mathrm{N}$ is moved and transformed in soils and groundwater (Katz and Eller 2016). Accounting for all of these things, NSILT then estimates how much $\mathrm{N}$ various sources contribute to the groundwater of each spring. Sources of $\mathrm{N}$ considered in the NSILT model include septic systems, atmospheric deposition ( $\mathrm{N}$ deposited from the atmosphere through rain or dry particles), fertilizers (both urban and agricultural), livestock waste, and wastewater treatment facilities. As shown in Table 2 and Figure 4, NSILT estimates of septic system contributions to the total $\mathrm{N}$ load to OFS vary from less than 2 percent to as much as 54 percent.

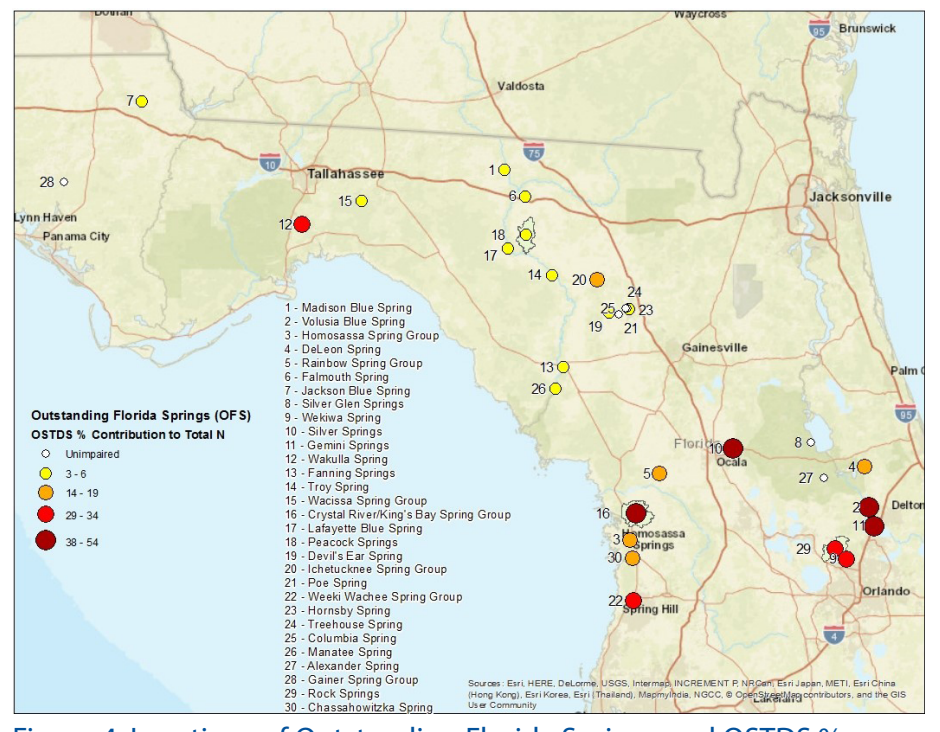

Figure 4. Locations of Outstanding Florida Springs and OSTDS \% contributions of total $\mathrm{N}$ to groundwater for each springshed. Credits: Kylie Chapman. Data Source: FDEP 
Among other requirements, the Florida Springs and Aquifer Protection Act (Chapter 373, Part VIII, Florida Statutes [F.S.]):

- Designates that FDEP must delineate a priority focus area (PFA) for each OFS; these PFAs are areas of the springshed where the aquifer is deemed especially vulnerable to pollutant inputs.

- Prohibits (among other activities) the following:

- Construction of new domestic wastewater treatment facilities (such as a central sewer facility) that do NOT treat sewage to at least a $3 \mathrm{mg} / \mathrm{L}$ level for nitrogen

- Installation of on-site sewage treatment and disposal systems on lots less than 1 acre

- Requires assessment of all OFS for nutrient impairments and the development of a Total Maximum Daily Load (TMDL) and Basin Management Action Plan (BMAP) anytime impairments are found. The TMDL is the maximum amount of a given pollutant allowed in the waterbody while still meeting water quality standards. TMDL goals must be met within 20 years of BMAP adoption. A BMAP is a management plan developed for a waterbody (spring, river, lake, or estuary) that does not meet the water quality standards set by the state. Once a waterbody is listed as impaired by one or more pollutants (nutrients, bacteria, or metals such as mercury), the FDEP sets a TMDL for each pollutant.

- Stipulates that if, during TMDL and BMAP development, on-site wastewater treatment and disposal systems (septic systems) are found to contribute at least 20 percent of non-point source $\mathrm{N}$ pollution, then local governments within the springshed must adopt a remediation plan to address this source of $\mathrm{N}$ loading. These remediation plans may include conversion to central sewer or replacement/ remediation of conventional septic tank systems with advanced N-removal technology.

For more information on the Florida Springs and Aquifer Protection Act, refer to EDIS document FE1019 (https:// edis.ifas.ufl.edu/fe1019).

\section{Managing Septic System N Loads to Springs}

As described above, the Florida Springs and Aquifer Protection Act stipulates that conventional OSTDS systems cannot be installed on lots less than 1 acre in size in the PFA of an Outstanding Florida Spring. Furthermore, if OSTDS systems are estimated to contribute at least 20 percent of the
$\mathrm{N}$ loading to a PFA (by using the NSILT model described above), then governments with jurisdiction must enact a remediation plan to address OSTDS $\mathrm{N}$ contributions. In some cases, this requirement is being met by converting conventional septic systems to central sewer facilities. In other cases, existing conventional septic systems are being retrofitted or replaced with advanced technology capable of enhanced $\mathrm{N}$ removal. Various commercial options are available that meet Florida Department of Health permitting requirements and FDEP requirements for advanced OSTDS $\mathrm{N}$ removal.

One of the simplest advanced technologies is an In-Ground Nitrogen Reducing Biofilter (INRB), which modifies an OSTDS drainfield with layers of soil specially designed to promote natural $\mathrm{N}$ cycling processes that convert $\mathrm{NO}_{3}^{-}$to an $\mathrm{N}$ gas that is lost to the atmosphere, thus removing $\mathrm{N}$ from the soil and groundwater (Figure 5). These modified drainfields may cost $\$ 10,000$ or more, but they can be highly effective for reducing $\mathrm{N}$ pollution to soils and groundwater. In these systems, septic tank effluent is first passed through a soil layer that promotes nitrification (conversion of $\mathrm{NH}_{4}^{+}$to $\mathrm{NO}_{3}^{-}$) and then through a second layer that promotes denitrification (conversion of $\mathrm{NO}_{3}{ }^{-}$to $\mathrm{N}_{2}$ gas). Each soil layer is specially designed to provide the environmental conditions necessary for microorganisms to carry out these processes naturally and for water to flow by gravity through the soil layers, without need for any electrical equipment such as a pump. While research is ongoing, early estimates are that the soil media in an INRB can function for $20+$ years before they need to be replaced or replenished. Homeowners and septic system industry personnel can check with their local county health department to find a list of approved technologies for advanced $\mathrm{N}$ removal if they live in an affected PFA. To see if you live in a PFA, you can use FDEP's interactive map (https://www. arcgis.com/apps/View/index.html?appid=1 afdd $97 \mathrm{c} 67584 \mathrm{c}$ 06840019241 becde74) by simply typing your address into the search bar.

\section{Conclusions}

There are over 2 million septic systems in Florida, a state with multiple natural springs flowing from groundwater that may be impacted by septic system inputs. In many areas of the state, conventional septic systems may be adequate for wastewater treatment and environmental protection, but in other areas-particularly those areas close to springs-septic systems are estimated to contribute hundreds of thousands of pounds of $\mathrm{N}$ to groundwater each year. This excess $\mathrm{N}$ can drive water quality impairments and harmful algal blooms. Therefore, increased efforts since 
2016 have placed emphasis on addressing septic systems as sources of $\mathrm{N}$ to springs. One of these efforts is the Florida Springs and Aquifer Protection Act, which outlines a set of requirements for instances when septic systems are found to contribute at least 20 percent of the $\mathrm{N}$ loading to the PFA of an Outstanding Florida Spring. In some cases, these requirements will involve replacing or retrofitting conventional septic systems with advanced $\mathrm{N}$ removal technology. Homeowners and septic system industry personnel should check FDOH and FDEP guidelines and publications to see if they are located within a PFA and should consider advanced OSTDS technology for enhanced $\mathrm{N}$ removal.

\section{References}

Brian, J. V., et al. 2007. "Evidence of Estrogenic Mixture Effects on the Reproductive Performance of Fish." Environmental Science \& Technology 41 (1): 337-344.

FDEP. 2018. Weeki Wachee Basin Management Action Plan. https://floridadep.gov/sites/default/files/Weeki\%20 Wachee\%20Final\%202018.pdf

Katz, B. G., and K. Eller. 2016. "The Nitrogen Source Inventory and Loading Tool (NSILT) and Restoration of Water-Quality Impaired Springs." Florida Scientist 79 (4): 299-310.

Lusk, M., et al. 2017. "A Review of the Fate and Transport of Nitrogen, Phosphorus, Pathogens, and Trace Organic Chemicals in Septic Systems." Critical Reviews in Environmental Science and Technology 47 (7): 455-541.

Meeroff, D. E., et al. 2008. "Evaluation of Water Quality Impacts of On-Site Treatment and Disposal Systems on Urban Coastal Waters." Water, Air, and Soil Pollution 192 (1-4): 11-24.

Toor, G. S., M. Lusk, and T. Obreza. 2011. Onsite Sewage Treatment and Disposal Systems: Nitrogen. SL348. Gainesville: University of Florida Institute of Food and Agricultural Sciences. https://edis.ifas.ufl.edu/ss550

Yang, Y., et al. 2016. "Septic Systems as Hot-Spots of Pollutants in the Environment: Fate and Mass Balance of Micropollutants in Septic Drainfields." Science of the Total Environment 566:1535-1544.
In-Ground Nitrogen-Reducing Biofilter (INRB)

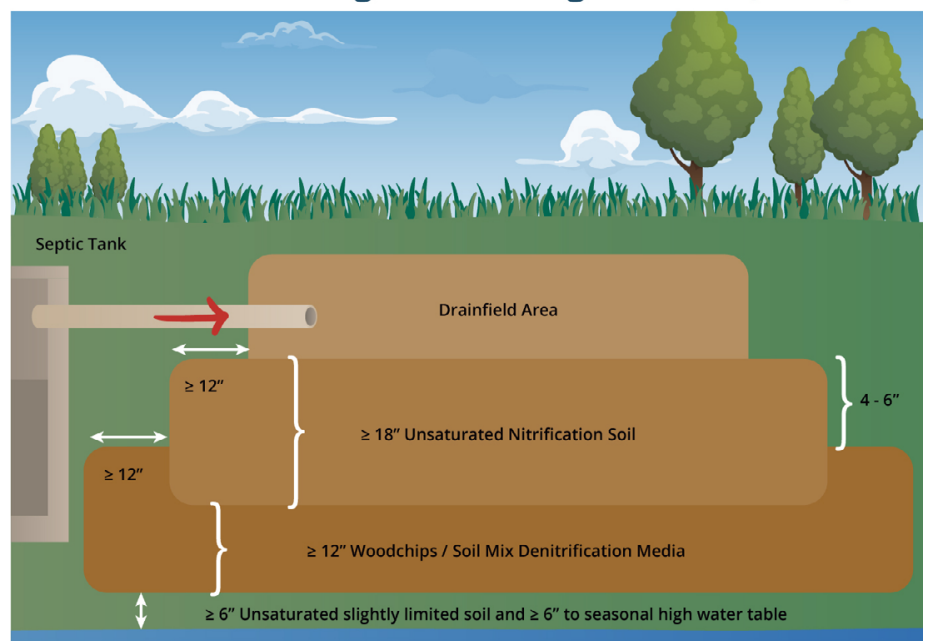

Figure 5. One example of an advanced technology for enhanced $\mathrm{N}$ removal from OSTDS systems.

Credits: UF/IFAS GCREC Urban Soil and Water Quality Lab 
Table 1. Florida requirements for setback distances between septic systems and various landscape features (gpd = gallons per day).

\begin{tabular}{|l|c|}
\hline \multicolumn{1}{|c|}{ Feature } & \multicolumn{1}{c|}{$\begin{array}{c}\text { Setback distance } \\
\text { (ft) }\end{array}$} \\
\hline Private potable well or multifamily well (3-4 residences) & 75 \\
\hline Public drinking-water well_-serves facility with sewage flow $\leq 2000 \mathrm{gpd}$ & 100 \\
\hline Public drinking-water well-serves facility with sewage flow $\geq 2000 \mathrm{gpd}$ & 200 \\
\hline Surface water body-mean high water line or annual flood line & 75 \\
\hline Nonpotable water well & 50 \\
\hline High water line of retention areas, detention areas, or swales & 15 \\
\hline
\end{tabular}

Table 2. Estimated N loads to groundwater for select Florida springs, based on estimates from the Florida Department of Environmental Protection.

\begin{tabular}{|c|c|c|c|}
\hline Springs name & Total N load (lb/yr) & $\begin{array}{c}\text { Estimated N load from septic } \\
\text { systems (lb/yr) }\end{array}$ & $\begin{array}{c}\text { Septic system N, percent } \\
\text { of total load }\end{array}$ \\
\hline Weeki Wachee & 940,144 & 282,875 & 30.0 \\
\hline Wakulla & 843,473 & 293,400 & 34.8 \\
\hline Devils Complex & $1,572,910$ & 89,271 & 5.7 \\
\hline Volusia Blue & 514,094 & 278,365 & 54.1 \\
\hline Silver & $1,661,273$ & 628,466 & 37.8 \\
\hline Rainbow & $1,328,073$ & 251,823 & 18.9 \\
\hline Chassohowitzka & 380,463 & 58,357 & 15.3 \\
\hline Homosassa & 582,175 & 96,116 & 16.5 \\
\hline Jackson Blue & 717,766 & 12,618 & 1.8 \\
\hline Ichetucknee & $1,657,089$ & 218,054 & 13.2 \\
\hline Hornsby & 503,624 & 59,198 & 11.8 \\
\hline Kings Bay & 591,530 & 250,174 & 42.3 \\
\hline Fanning/Manatee & $2,332,702$ & 61,822 & 2.7 \\
\hline Troy/Falm/LafBI/Peac & $4,274,798$ & 108,122 & 2.5 \\
\hline Madison Blue & 451,424 & 16,833 & 3.7 \\
\hline DeLeon & 205,708 & 28,800 & 14.0 \\
\hline Gemini & 50,762 & 21,633 & 42.6 \\
\hline Wekiwa/Rock & $1,023,703$ & 296,984 & 29.0 \\
\hline Wacissa & 572,645 & 22,280 & 3.9 \\
\hline
\end{tabular}

